\title{
Solubility and Permeability Studies of Aceclofenac in Different Oils
}

\author{
Muhammad Zubair Malik, Mahmood Ahmad*, Muhammad Usman Minhas and \\ Abubakar Munir
}

Department of Pharmacy, Faculty of Pharmacy and Alternative Medicine, The Islamia University of Bahawalpur-63100, PunjabPakistan

*For correspondence: Email: ma786_786@yahoo.com; Tel: +92-0300-9682258

Received: 1 February 2013

Revised accepted: 14 January 2014

\begin{abstract}
Purpose: To measure the extent of solubility of the lipophilic drug, aceclofenac, in 13 oils as well as its in vitro permeability from these oils in order to develop optimized topical microemulsion and microemulsion-based gel for improved bioavailability.

Methods: UV spectrophotometeric method was used at the wavelength of $276 \mathrm{~nm}$ to measure the dissolved quantity of aceclofenac in each of the oils (almond oil, oleic acid, castor oil, paraffin oil, cinnamon oil, clove oil, canola oil, sesame oil, isopropyl myristate (ipm), sunflower oil, corn oil, coconuts oil and eucalyptus oil) at $25{ }^{\circ} \mathrm{C}$. The in-vitro permeability of aceclofenac in each of these oils was determined at $32 \pm 0.5^{\circ} \mathrm{C}$ using Franz diffusion cell with phosphate buffer $(\mathrm{pH} 7.4$ ) as medium with 0.45 $\mu$ cellulose acetate membrane. The solubility and permeability of aceclofenac were compared with the hydroalcoholic solution of aceclofenac.

Results: The highest solubility values of 9.153 and $8.560 \mathrm{mg} / \mathrm{ml}$ for aceclofenac were obtained with almond oil and oleic acid, respectively $(p<0.05)$. However the solubility and permeability of aceclofenac in hydro-alcoholic solution were $150.65 \mathrm{mg} / \mathrm{ml}$ and $14.91 \pm 0.05 \mu \mathrm{g} / \mathrm{cm}^{2} / \mathrm{h}$, respectively. Aceclofenac also showed higher permeability values (1.45 0.04 and $1.21 \pm 0.06)$ in almond oil and oleic acid, respectively, than in the other oils $(p<0.05)$.

Conclusion: These findings show that almond oil and oleic acid are promising vehicles for aceclofenac as its enhanced solubility and permeability in these vehicles are suggestive of improved bioavailability.
\end{abstract}

Keywords: Aceclofenac, Almond oil, Solubility; Permeability, Oleic acid, Bioavailability.

Tropical Journal of Pharmaceutical Research is indexed by Science Citation Index (SciSearch), Scopus, International Pharmaceutical Abstract, Chemical Abstracts, Embase, Index Copernicus, EBSCO, African Index Medicus, JournalSeek, Journal Citation Reports/Science Edition, Directory of Open Access Journals (DOAJ), African Journal Online, Bioline International, Open-J-Gate and Pharmacy Abstracts

\section{INTRODUCTION}

The in vitro rate and extent of permeability of a drug from dosage forms are good markers to assess the in vivo bioavailability of the drug [1]. Forty percent of new chemical entities (NCEs) and many existing drugs are poorly soluble compounds which lead to poor in vivo bioavailability, high intra- and inter-subject variability and lack of dose proportionality [2-4].
An approach to enhancing the solubility or bioavailability of poorly soluble compounds is the use of lipid based systems such as micro- or nano-emulsions, solid lipid nanosuspensions, niosomes and liposomes. Formulation scientists increasingly turn to a range of nanotechnology-based solutions to improve solubility, dissolution and bioavailability of poorly soluble compounds $[3,4]$. Various delivery systems have been investigated successfully to improve the 
solubility, dissolution and in vivo bioavailability of poorly soluble drugs [2-10].

Aceclofenac (2-[2-[2-[(2,6-dichlorophenyl)amino]phenyl]acetyl] oxyacetic acid) (Fig 1), as NSAID has been recommended for the treatment of various kinds of pains, osteoarthritis and rheumatoid arthritis [8].<smiles>O=C(O)COC(=O)Cc1ccccc1Nc1c(Cl)cccc1Cl</smiles>

Fig 1: Structure of aceclofenac

Aceclofenac is well absorbed after oral administration with hepatic first-pass metabolism [11]. Due its poor aqueous solubility which poses a dissolution-related absorption problem, an attempt has been made to improve its solubility and dissolution using different oils $[12,13]$. The aim of the present investigation was to find suitable oils that would improve solubility and in vitro permeation of aceclofenac with a view to enhancing its in vivo release from dosage forms.

\section{EXPERIMENTAL}

\section{Chemicals}

Aceclofenac was obtained as a gift from Sami Laboratories (Karachi, Pakistan). Almond oil, oleic acid, castor oil, paraffin oil, cinnamon oil, clove oil, canola oil, sesame oil, isopropyl myristate (ipm), sunflower oil, corn oil, coconuts oil and eucalyptus oil were purchased from Sigma Aldrich. All other chemicals used in the study were of analytical grade.

\section{Equipment}

Hot plate magnetic stirrer (Velp Scientifica, Germany), pH meter (Inolab, Germany), Digital weighing balance (Shimadzu, AUX 220, Japan), Centrifuge Machine (Hettich, Germany), Ultra sonic bath (Elma, Germany), Ultra low refrigerator (Germany). Cellulose acetate filter paper (Sartorius), Double beam Spectrophotometer Shimadzu, Japan.
Preparation of calibration curves for aceclofenac

Each of the oils was investigated for their solubility in methanol, ethanol, isopropyl alcohol and n-butanol to construct their calibration curves in the various solvents since aceclofenac is freely soluble in these solvents. The stock solutions of aceclofenac were prepared in each of these solvents. Serial dilutions comprising of 0.312 , $0.625,1.25,2.5,5,10$ and $20 \mu \mathrm{g} / \mathrm{ml}$ were made from the respective stock solutions.

\section{Determination of solubility of aceclofenac in various oils}

The solubility of aceclofenac in distilled water, nano-emulsion, solid lipid nano-suspensions (SLN) and polymeric nano-suspensions (PN (method was selected due to its application in lipids which is similar tooils) was determined by UV spectrophotometer at the wavelength of 276 $\mathrm{nm}$ [8]. Excess amount of aceclofenac in all sample matrices $(5 \mathrm{ml}$ of each oil) were placed in $20 \mathrm{ml}$ stoppered glass vials in triplicate. These stoppered glass vials were agitated in a mechanical shaker water bath (Memmert, Germany) at $25 \pm 1{ }^{\circ} \mathrm{C}$ for $72 \mathrm{~h}$ to reach equilibrium. Thereafter, the solutions were filtered through $0.45 \mu$ filter, diluted suitably with the respective organic solvent and evaluated spectrophotometrically for aceclofenac content at $276 \mathrm{~nm}[8]$.

\section{In vitro permeability studies}

Aceclofenac solution (equivalent to $2 \mathrm{mg}$ aceclofenac) in each oil was placed in the donor compartment of a Franz diffusion cell $0.45 \mu$ pore cellulose acetate membrane separating it from the receptor compartment containing phosphate buffer $(\mathrm{pH} 7.4)$ at $32 \pm 0.5{ }^{\circ} \mathrm{C}$. The donor compartment was covered with aluminum foil to prevent drying of the oil. Samples $(300 \mu \mathrm{l})$ were withdrawn at regular intervals over a 24-h period and replaced with the same volume of fresh phosphate buffer. Drug content was determined spectrophotometrically at $276 \mathrm{~nm}$ [8].

\section{Statistical analysis}

The mean and standard error of mean (SEM, $n=$ 6 ) of the data were calculated. Statistically significant differences were analyzed by one-way analysis of variance (ANOVA) Comparison of the solubility values of aceclofenac in the studied lipid mediums and hydroalcoholic solution using MedCalc software at $95 \%$ confidence level. 
Table 1: Solubility and permeability of aceclofenac in various oils (mean \pm SEM, $n=6$ )

\begin{tabular}{|c|c|c|c|}
\hline Oil & $\begin{array}{l}\text { Solubility } \\
\text { (mg/ml) }\end{array}$ & Flux $\left(\mu \mathrm{g} / \mathrm{cm}^{2} / \mathrm{h}\right)$ & $\begin{array}{c}\text { Permeability } \\
\text { coefficient } \\
\left(\mathrm{cm} / \mathrm{h}, \times 10^{-3}\right) \\
\end{array}$ \\
\hline Almond oil* & $9.163 \pm 0.055$ & $1.451 \pm 0.042$ & $0.072 \pm 0.006$ \\
\hline Oleic acid* & $8.560 \pm 0.023$ & $1.212 \pm 0.065$ & $0.061 \pm 0.003$ \\
\hline Castor oil & $1.333 \pm 0.034$ & $0.997 \pm 0.081$ & $0.049 \pm 0.002$ \\
\hline Cinnamon oil & $1.056 \pm 0.087$ & $1.067 \pm 0.046$ & $0.053 \pm 0.003$ \\
\hline Clove oil & $0.826 \pm 0.069$ & $1.080 \pm 0.023$ & $0.054 \pm 0.004$ \\
\hline Canola oil & $2.047 \pm 0.082$ & $0.968 \pm 0.068$ & $0.048 \pm 0.003$ \\
\hline Isopropyl Myristate IPM & $4.097 \pm 0.021$ & $1.095 \pm 0.012$ & $0.055 \pm 0.003$ \\
\hline Sesame oil & $4.351 \pm 0.237$ & $1.029 \pm 0.029$ & $0.051 \pm 0.004$ \\
\hline Sunflower oil & $1.103 \pm 0.033$ & $1.080 \pm 0.032$ & $0.054 \pm 0.006$ \\
\hline Corn oil & $0.296 \pm 0.044$ & $1.048 \pm 0.045$ & $0.052 \pm 0.005$ \\
\hline $\begin{array}{l}\text { Coconut oil } \\
\text { Paraffin oil } \\
\text { Eucalyptus oil } \\
\text { Hydroalcoholic solution }\end{array}$ & $\begin{array}{c}0.365 \pm 0.065 \\
0.758 \pm 0.042 \\
1.831 \pm 0.041 \\
150.65 \pm 0.063\end{array}$ & $\begin{array}{l}1.061 \pm 0.053 \\
0.935 \pm 0.081 \\
0.955 \pm 0.027 \\
14.912 \pm 0.051\end{array}$ & $\begin{array}{l}0.053 \pm 0.007 \\
0.045 \pm 0.004 \\
0.048 \pm 0.006 \\
0.746 \pm 0.041\end{array}$ \\
\hline
\end{tabular}

\section{RESULTS}

Both solubility and permeability results for aceclofenac are presented in Table 1. The highest solubility values of 91.53 and $85.6 \mathrm{mg} / \mathrm{ml}$ for aceclofenac were obtained with almond oil and oleic acid, respectively $(p<0.05)$. Aceclofenac also showed higher permeability $(1.45 \pm 0.04$ and $1.21 \pm 0.06)$ in almond oil and oleic acid, respectively, than in the other oils $(p<$ 0.05).

\section{DISCUSSION}

Solubility is one of the important parameters to achieve desired concentration of drug in systemic circulation in order to elicit pharmacological response. Drug efficacy can be severely limited by poor aqueous solubility and some drugs also show side effects due to their poor solubility [17]. Therefore, the solubility of aceclofenac in different oils was determined in triplicate and compared with hydroalcoholic solution statistically using oneway ANOVA. The solubility of aceclofenac in hydroalcoholic solution and different oils is presented in Table 1. The solubility of aceclofenac in hydroalcoholic solution was found to be $150.65 \mathrm{mg} / \mathrm{ml}$ at $25^{\circ} \mathrm{C}$. The solubility of aceclofenac in almond oil and oleic acid was extremely significant as compared to its hydroalcoholic solubility $(P<0.05)$. Highest solubility of aceclofenac was found in almond oil among studied oils. The permeability studies of aceclofenac from hydroalcoholic solution and different oils were performed in phosphate buffer at $\mathrm{pH}$ 7.4. The flux $\left(\mathrm{J}_{\mathrm{ss}}\right)$ and permeability coefficient $\left(K_{p}\right)$ of aceclofenac were highest in almond oil $\left(1.45 \mu \mathrm{g} / \mathrm{cm}^{2} / \mathrm{h}\right.$ and $0.073 \mathrm{~cm} / \mathrm{h}$ at $32 \pm$ $0.5^{\circ} \mathrm{C}$ ) after $24 \mathrm{~h}$ as shown in Table 1 . This indicates that the presence of oils (containing unsaturated fatty acids) can significantly enhance the permeability of a poorly soluble drug aceclofenac [15]. A general trend can be seen where unsaturated fatty acids are more effective in enhancing percutaneous absorption of drugs than their saturated counterparts [16].

The solubility of aceclofenac is higher in unsaturated fatty acids than in triglycerides. Almond oil contains more than $90 \%$ unsaturated fatty acids (68\% oleic acid and $25 \%$ linoleic acid [14]) whereas oleic acid itself is an unsaturated fatty acid. That is the why solubility of aceclofenac is higher in almond oil and oleic acid than in other oils which do not contain unsaturated fatty acids.

\section{CONCLUSION}

Almond oil and oleic acid are promising carriers/vehicles for enhanced solubility and permeability of aceclofenac. Thus, these oils can be used to develop drug delivery systems for improved bioavailability of aceclofenac.

\section{ACKNOWLEDGEMENT}

The authors are thankful to Higher Education Commission of Pakistan and the administration of Faculty of Pharmacy and Alternative Medicine, the Islamia University of Bahawalpur, for providing facilities to carry out this work. 


\section{REFERENCES}

1. Ahmed SM, Abdel-Rahman AA, Saleh SI, Ahmed MO. Comparative dissolution characteristics of bropirimine- beta-cyclodextrin inclusion complex and its solid dispersions with PEG-6000. Int $\mathrm{J}$ Pharm 1993; 96: 5-11.

2. Baboota S, Faisal MS, Ali J, Ahuja A. Effect of poloxamer 188 on the lymphatic uptake of carvedilol loaded solid lipid nanoparticles for bioavailability enhancement. J Drug Target 2009; 17: 249-256.

3. Shakeel F, Baboota S, Ahuja A, Ali J, Shafiq S. Celecoxib nanoemulsion: Skin permeation mechanism and bioavailability assessment. J Drug Target 2008; 16. 733-740.

4. Shakeel F, Baboota S, Ahuja A, Ali J, Shafiq S. Skin permeation mechanism and bioavailability enhance-ment of celecoxib from transdermally applied nanoemulsion. J Nanobiotech 2008b; 6: E8.

5. Labhastwar V, Song C Levy RJ. Nanoparticle drug delivery system. Adv Drug Del Rev 1997; 24: 63-85.

6. Shafiq S, Shakeel F, Talegaonkar S, Ahmad FJ, Khar RK, Ali M. Design and development of ramipril nanoemulsion formulation: In vitro and in vivo assessment. J Biomed Nanotech 2007; 3: 28-44.

7. Shafiq S, Shakeel F, Talegaonkar S, Ahmad FJ, Khar RK. Development and bioavailability as-sessment of ramipril nanoemulsion formulation. Eur $J$ Pharm Biopharm 2007b; 66: 227-242.

8. Shakeel $F$, Baboota $S$, Ahuja A, Ali J, Aqil $M$. Nanoemulsions as vehicles for transdermal delivery of aceclofenac. AAPS Pharm Sci Tech 2007; 8: E104.

9. Baboota S, Faisal MS, Ali J, Ahuja A. Effect of poloxamer 188 on the lymphatic uptake of carvedilol loaded solid lipid nanoparticles for bioavailability enhancement. J Drug Target 2009; 17: 249-256.

10. Shakeel F, Ramadan W, Shafiq S. Solubility and Dissolution Improvement of Aceclofenac using Different Nanocarriers. J Bioeq Avail. 2009; 1: 039043.

11. Shakeel F, Faisal MS, Shafiq S. Comparative pharmacokinetic profile of aceclofenac after oral and transdermal application. J Bioeq Avail 2009; 1: 13-17.

12. Shafiq S, Shakeel F, Talegaonkar S, Ali J, Baboota S, Ahuja A, Khar RK, Ali M. Formulation development and optimization using nanoemulsion technique: $A$ technical note. AAPS PharmSciTech 2007; 8: Article 28.

13. Shafiq S, Shakeel F. Enhanced stability of ramipril in nanoemulsion containing Cremophor-EL: $A$ technical note. AAPS PharmSciTech. 2008; 9: 1097-1101.

14. Kimura Y, Hosoda $Y$, Shima M, Adachi S, Matsuno R. Physicochemical properties of fatty acids for assessing the threshold concentration to enhance the absorption of a hydrophilic substance. Biosci Biotechnol Biochem. 1998; 62(3): 443-447.

15. Shi Z, Fu Q, Chen B, Xu S. Analysis of physicochemical property and composition of fatty acid of almond oil. Chinese J Chromatogr. 1999; 17(5): 506-7.

16. Sinha V. R. and Kaur M. P. Permeation Enhancers for Transdermal Drug Delivery. Drug Dev Ind Pharm. 2000; 26(11): 1131-1140.

17. Amit C, Upendra N, Neha G., Sharma VK, Khosa RL. Enhancement of solubilization and bioavailability of poorly soluble drugs by physical and chemical modifications: A recent review. J Adv Pharm EducRes. 2012; 2(1): 32-67. 